\title{
A Comparative study between Traditional and Innovative school teachers perceptions regarding medical certificate for newly graduated doctors
}

\author{
Wafa Mahmood Jasim ${ }^{1}$, Waleed Ghanium Anmar ${ }^{2}$, Ahmed B. Al-Dewachi ${ }^{3}$ \\ Wafamahmod396@yahoo.com \\ ${ }^{1}$ Northern technical university, Kirkuk Technical Institute, Nursing dept, Iraq \\ ${ }^{2}$ Department of Family and Community Medicine College of Medicine-University of Mosul, Mosul, Iraq \\ ${ }^{3}$ Assistant Professor/Department of Family and Community Medicine \\ College of Medicine-University of Mosul, Mosul, Iraq
}

\begin{abstract}
Certification is defined by the (National Organization for Competency Assurance) as the process by which a non- governmental agency grants recognition of competence to an individual who has met predetermined qualifications specified by that agency. The study was aimed to compare the teacher's perceptions of both (Traditional and Innovative ) schools regarding the medical certificate given to newly graduated doctors. A descriptive cross-sectional study was conducted on Mosul \& Nineveh and Tikrit medical schools during the period from $1^{\text {st }}$ April till $30^{\text {th }}$ June / 2013. 376 medical teachers were included in the study (243) from traditional school (Mosul \& Nineveh) and (133) from innovative school (Tikrit ) after distributing a special questionnaire form and face to face interview was performed after receiving their written consent. The study show that both teachers from traditional and innovative medical schools disagree with giving the medical certificate directly after graduation $(92-79.1 \%)$, (77$57.8 \%$ ) respectively. On the other hand, traditional medical teachers agree with the need for an advanced training program about 3-4 months after graduation and before participating in their job in comparison to (33-42.8\%) of innovative medical teachers who agree with 1-2 months period training program. Further intended specific educational training program concentrated on the clinical and ethical issues that is needed and essential for their future job.
\end{abstract}

Keywords: Perception, Newly doctors, Traditional school, Tikrit

\section{Introduction}

Graduate medical education usually defined as the education in which the physician receives after complete residency and training period as a fellowship of finishing the medical school, while other countries called this period as specialty training or postgraduate education $[1,2]$. Graduate training usually referred to as the phase of acquiring a wide range of clinical experience through the daily practice of both ( the basic skills and clinical judgment ) [3]. and for the above reasons, the period of undergraduate education and the residency practice together comprise the basic medical education for future doctors [4]. 
The necessary completion of medical school education should provide students with a higher level of essential knowledge and skills which are very beneficial for junior new doctors in order to complete their future daily duty at the hospital $[4,5]$.

Different investigators mentioned that examination results don't present the truth residents' level of confidence or feeling of responsibilities and preparedness towards fitness for their job [5].

A positive - self-assessment of a person ability is very important as a part of successful graduation because it is influencing carrier choice, performance in a place where the in competencies are perceived, therefore new doctors should feel that they are well prepared for their future duties and experiences to get rid and overcome any few deficits that can occur besides the passing of a final exam [6,7].

Clinical training is based on apparent ship model, so medical teachers describe what must the students know and do by himself then examine the ability for doing it; however, in reality, most clinical activities are related with health problems for which there are no evident a clear single answer is present, so in these cases, an experienced scientific doctors look for a presence of a wide range of options while in rare case the solution will be something that never arrived at before $[8,9]$.

Clinical competence itself is of significant value as a prerequisite for performance in hospitals or any setting and usually, there is no association with performance in practice [10].

\section{The aim of the study}

The study was aimed to compare medical teachers' perceptions of both (Traditional and Innovative ) schools regarding the medical certificate given to newly graduated doctors.

Methodology:-

1- A administrative agreement

Official permission was taken from (Nineveh \&Mosel ) and Tikrit medical colleges before establishing the study.

2- Study setting:-

The study was carried out in (Nineveh \&Mosel) and Tikrit medical college.

3- Study sample and sampling method:-

A descriptive study was conducted among medical teachers in traditional medical schools (Nineveh \&Mosel) and innovative medical school (Tikrit) and 376 teachers from both basic and clinical departments were included in the study ( 243 teachers from traditional school and 133 from innovative school).

A special questionnaire form was distributed to them after receiving their written consent from them and the data was collected by direct interviewing after complete explanation of the study aim.

4- Study period :

The study was conducted during the period from $1^{\text {st }}$ April till $30^{\text {th }}$ June / 2013 according to special time table which has been prepared by the investigator

5- Data collection tool :

A special designed questionnaire form has been prepared utilizing available updated related books to the questionnaire item included for main parts :- 
Part-1-Demographic characteristics including ( age, gender, certificate, a period in teaching, specialty and scientific degree)which has been taken from the unit of human resources at each medical collage .

Part-2-Teachers perceptions about time of giving the medical certificate.

Part-3-Teachers perceptions about the suggested duration of training program.

Part-4-Teachers perceptions regarding the essential topics included in the training program after graduation.

Part-5-Teaches perceptions about the future suggestions for training program improvement Inclusion criteria :

All the medical teachers were included from both basic and clinical departments.

6- Statistical analysis of data:-

All the statements with yes and no answer, number and percent was calculated .

Chi- square test was used to detect the relation between the studied variables and 5\% (P< $0.05)$ was considered significant.

\section{Results}

Table 1. Frequency distribution of study medical schools teachers according to their socio-demographic characteristics

\begin{tabular}{|c|c|c|c|c|c|}
\hline \multicolumn{2}{|c|}{ Socio demographic parameter } & \multirow{2}{*}{$\begin{array}{c}\text { Traditional school } \\
\text { (Mosul \&Nineveh) } \\
\text { N=243 } \\
\text { No. }\end{array}$} & \multirow{2}{*}{ 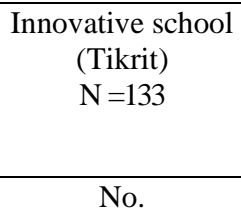 } & \multicolumn{2}{|c|}{$\begin{array}{c}\text { Total } \\
\mathrm{N}=376\end{array}$} \\
\hline & & & & No. & $\%$ \\
\hline Gender & $\begin{array}{l}\text { Male } \\
\text { female }\end{array}$ & $\begin{array}{l}142 \\
101\end{array}$ & $\begin{array}{l}83 \\
50\end{array}$ & $\begin{array}{l}225 \\
151\end{array}$ & $\begin{array}{l}\mathbf{5 9 . 8} \\
40.2\end{array}$ \\
\hline $\begin{array}{l}\text { Age group } \\
\text { (in years ) }\end{array}$ & $\begin{array}{c}30-39 \\
40-49 \\
50-59 \\
>60\end{array}$ & $\begin{array}{c}71 \\
90 \\
78 \\
4 \\
\end{array}$ & $\begin{array}{l}17 \\
69 \\
35 \\
12\end{array}$ & $\begin{array}{c}88 \\
159 \\
113 \\
16\end{array}$ & $\begin{array}{c}23.4 \\
42.3 \\
30.1 \\
4.2\end{array}$ \\
\hline Certificate & $\begin{array}{l}\text { Master of science } \\
\text { Board (Iraqi and } \\
\text { Arabian) PhD }\end{array}$ & $\begin{array}{c}91 \\
35 \\
117\end{array}$ & $\begin{array}{l}31 \\
43 \\
59\end{array}$ & $\begin{array}{c}122 \\
78 \\
176\end{array}$ & $\begin{array}{l}32.4 \\
20.7 \\
46.9\end{array}$ \\
\hline Specialty & $\begin{array}{c}\text { Basic sciences } \\
\text { Clinical sciences }\end{array}$ & $\begin{array}{c}164 \\
79\end{array}$ & $\begin{array}{l}51 \\
82\end{array}$ & $\begin{array}{l}215 \\
161\end{array}$ & $\begin{array}{l}57.1 \\
42.9\end{array}$ \\
\hline Period in teaching & $\begin{array}{c}<5 \text { years } \\
5-10 \text { years } \\
>10 \text { years }\end{array}$ & $\begin{array}{c}26 \\
137 \\
80\end{array}$ & $\begin{array}{l}12 \\
84 \\
37\end{array}$ & $\begin{array}{c}38 \\
221 \\
117\end{array}$ & $\begin{array}{l}10.1 \\
58.7 \\
31.2\end{array}$ \\
\hline Scientific degree & $\begin{array}{c}\text { Professor } \\
\text { Assistant professor } \\
\text { Lecturer } \\
\text { Assistant lecturer }\end{array}$ & $\begin{array}{c}6 \\
66 \\
100 \\
71\end{array}$ & $\begin{array}{c}5 \\
67 \\
48 \\
13 \\
2.8 \\
21.1 \\
53.5 \\
22.6\end{array}$ & $\begin{array}{c}11 \\
133 \\
148 \\
84\end{array}$ & $\begin{array}{c}2.9 \\
35.3 \\
39.4 \\
22.4\end{array}$ \\
\hline
\end{tabular}


Table 1 shows that $59.8 \%$ of studied schools teachers were male, $42.3 \%$ within the age group $40-49$ years, $46.9 \%$ have $\mathrm{PhD}$ certificate, $57.1 \%$ were from basic medical sciences, $58.7 \%$ with a period in teaching $5-10$ years and $39.4 \%$ of them were lecturers

Table 2. Time of giving the medical certificate

\begin{tabular}{|c|c|c|c|c|c|c|c|c|c|}
\hline \multirow{4}{*}{$\begin{array}{l}\text { Time for giving the } \\
\text { certificate }\end{array}$} & \multicolumn{8}{|c|}{ Teachers perceptions } & \multirow{4}{*}{$\begin{array}{c}\mathrm{P}^{*} \\
\text { Value }\end{array}$} \\
\hline & \multicolumn{4}{|c|}{$\begin{array}{l}\text { Traditional schools } \\
\text { (Mosul \&Nineveh) } \\
\text { N=243 }\end{array}$} & \multicolumn{4}{|c|}{$\begin{array}{c}\text { Innovative school } \\
\text { (Tikrit) } \\
\mathrm{N}=133\end{array}$} & \\
\hline & \multicolumn{2}{|c|}{ Agree } & \multicolumn{2}{|c|}{ Disagree } & \multicolumn{2}{|c|}{ Agree } & \multicolumn{2}{|c|}{ Disagree } & \\
\hline & No. & $\%$ & No. & $\%$ & No. & $\%$ & No. & $\%$ & \\
\hline $\begin{array}{l}\text { Gives directly after } \\
\text { completing a } 6 \\
\text { years study }\end{array}$ & 95 & 39.1 & 148 & 60.9 & 56 & 42.1 & 77 & 57.9 & 0.569 \\
\hline $\begin{array}{l}\text { Postponed after a } \\
\text { professional } \\
\text { training course }\end{array}$ & 165 & 67.9 & 78 & 32.1 & 91 & 68.4 & 42 & 31.6 & 0.019 \\
\hline $\begin{array}{l}\text { Completing } 1 \text { year } \\
\text { residency period }\end{array}$ & 158 & 65.0 & 85 & 35.0 & 102 & 76.7 & 31 & 23.3 & 0.918 \\
\hline
\end{tabular}

$* \chi^{2}-$ test was used

Table 2 shows that $67.9 \%$ of medical teachers from Mosul and Nineveh schools agree with postponing the certificate giving after a professional training course with p-value $=0.019$ while $76.7 \%$ teachers from innovative school agree with giving the certificate after completing 1 year residency period with a $\mathrm{P}$-value $=0.918$

Table 3. Distribution of study medical teachers according to their perceptions regarding the suggested training program

Note Teachers with answers :

1 - It should be given directly after completing a 6 years study

2 - It should be postponed after completing 1 year residency period

Were excluded from the study

\begin{tabular}{|c|c|c|c|c|}
\hline $\begin{array}{c}\text { Duration of } \\
\text { the suggested } \\
\text { training } \\
\text { program }\end{array}$ & $\begin{array}{c}\text { Traditional schools } \\
\text { (Mosul \&Nineveh) } \\
\mathrm{N}=165\end{array}$ & $\begin{array}{c}\text { Innovative school } \\
\text { (Tikrit) } \\
\mathrm{N}=91\end{array}$ & $\begin{array}{c}\text { Total } \\
\%\end{array}$ & $\begin{array}{c}\mathrm{P}^{*} \\
\text { Value }\end{array}$ \\
\hline $\begin{array}{c}1-2 \text { months } \\
\text { period }\end{array}$ & $44(26.7 \%)$ & $45(49.5 \%)$ & 89 \\
\hline $\begin{array}{c}3-4 \text { months } \\
\text { period }\end{array}$ & $95(57.6 \%)$ & $22(24.2 \%)$ & $34.7 \%$ & 0.000 \\
\hline $\begin{array}{c}>4 \text { months } \\
\text { period }\end{array}$ & $26(15.7 \%)$ & $24(26.3 \%)$ & $50.7 \%$ & 0.023 \\
\hline $\begin{array}{l}\chi^{2}-\text { test was used } \\
\text { n }\end{array}$ & & $19.6 \%$ & 0.000 \\
\hline
\end{tabular}


Table 3 shows that $57.6 \%$ of traditional school teachers go with the suggested needed training program for about 3-4 months in comparison to $49.5 \%$ of innovative school teachers go with the needed for 1-2 months with a P-value $=0.000$.

Table 4. Medical teachers perceptions regarding the main topics included in the training program

\begin{tabular}{|c|c|c|c|c|}
\hline $\begin{array}{l}\text { Suggested training } \\
\text { program }\end{array}$ & $\begin{array}{c}\begin{array}{c}\text { Traditional } \\
\text { schools } \\
\text { (Mosul \&Nineveh) }\end{array} \\
\mathrm{N}=165\end{array}$ & $\begin{array}{c}\text { Innovative school } \\
\text { (Tikrit) }\end{array}$ & $\begin{array}{c}\text { Total } \\
\%\end{array}$ & $\begin{array}{c}\mathrm{P}^{*} \\
\text { Value }\end{array}$ \\
\hline $\begin{array}{c}\text { Clinical training } \\
\text { only }\end{array}$ & $27(16.3 \%)$ & $52(57.1 \%)$ & $\begin{array}{c}79 \\
(30.9 \%)\end{array}$ & $\begin{array}{c}0.00 \\
0\end{array}$ \\
\hline $\begin{array}{l}\text { Basic essential } \\
\text { skills }\end{array}$ & $45(27.3 \%)$ & $15(16.5 \%)$ & $\begin{array}{c}60 \\
(23.4 \%)\end{array}$ & $\begin{array}{c}0.05 \\
1\end{array}$ \\
\hline $\begin{array}{c}\text { Both of them } \\
\text { (Basic +clinical ) }\end{array}$ & $93(56.4 \%)$ & $24(26.4 \%)$ & $\begin{array}{c}117 \\
(45.7 \%)\end{array}$ & $\begin{array}{c}0.00 \\
1\end{array}$ \\
\hline
\end{tabular}

$\chi^{2}-$ test was used

Table 4 shows that $56.4 \%$ of traditional medical teachers go with application of both of basic essential skills and clinical training in suggestive course training in comparison to $57.1 \%$ of innovative medical teachers go with application of only clinical training with a p-value $=0.000$

Table 5. Medical teachers perceptions regarding future suggestions for improving the training program

\begin{tabular}{|c|c|c|c|c|c|c|c|c|}
\hline \multirow{4}{*}{$\begin{array}{l}\text { Future suggestions for } \\
\text { improving the training } \\
\text { program }\end{array}$} & \multicolumn{8}{|c|}{ Medical teachers perceptions } \\
\hline & \multicolumn{4}{|c|}{$\begin{array}{l}\text { Traditional schools } \\
\text { (Nineveh) } \\
\mathrm{N}=165\end{array}$} & \multicolumn{4}{|c|}{$\begin{array}{c}\text { Innovative school } \\
\text { (Tikrit) } \\
\text { N=91 }\end{array}$} \\
\hline & \multicolumn{2}{|c|}{ Basic } & \multicolumn{2}{|c|}{ Clinical } & \multicolumn{2}{|c|}{ Basic } & \multicolumn{2}{|c|}{ Clinical } \\
\hline & No. & $\%$ & No. & $\%$ & No. & $\%$ & No. & $\%$ \\
\hline $\begin{array}{l}\text { 1- College } \\
\text { administrative support }\end{array}$ & 11 & $12.3 \%$ & 16 & 21.1 & 29 & $34.3 \%$ & 7 & $29.2 \%$ \\
\hline $\begin{array}{l}\text { 2- Adequate financial } \\
\text { resources }\end{array}$ & 25 & $28.2 \%$ & 14 & 18.4 & 15 & $22.4 \%$ & 10 & $41.7 \%$ \\
\hline $\begin{array}{l}\text { 3- Advanced updated } \\
\text { training program }\end{array}$ & 31 & $34.8 \%$ & 27 & 30.5 & 18 & $26.9 \%$ & 5 & $20.8 \%$ \\
\hline $\begin{array}{l}\text { 4- Hospital based } \\
\text { training }\end{array}$ & 22 & $24.7 \%$ & 19 & 25.0 & 5 & $7.4 \%$ & 2 & $8.3 \%$ \\
\hline Total & 89 & & 76 & & 67 & & 24 & \\
\hline
\end{tabular}


Table 5 presents that traditional medical teachers from both basic and clinical departments suggested an advanced updated training program to get better future results $(34.8 \%$, and $30.5 \%$ ) respectively.

For the innovative school, the medical teachers from basic departments suggested the necessity for college administrative support (34.3\%)in comparison to traditional schools which suggested adequate finical training program for a staff member to increase their ability about the correct application of it.

\section{Discussion}

Regarding the graduation certificate, a study was done by Farhana / 2012 [11]. who mentioned that junior doctors are often inundated with an invitation to conducting in a training program that varies widely from optional program presentation skills to mandatory training for preparing the doctors for future duties to be a good practitioner tomorrow doctor. She also reported in her study that the main useful outcome from these training courses during postgraduation period in medical practice should be continued and not accepted until full completing these programs

Concerning the suggested training program the current study shows that there is a need for about 3-4 months. Dr. Syed / 2012 [12]. said during his workshop on the accreditation of health professions education, with special attention on medical education that newly graduated doctors are required to master core clinical competencies and obtained a wide range of cultural competencies to maintain that they are in - tune with the needs of populations and communities support their communities and necessary requirements should be conducted for accreditation systems like medical certificate.

The training program should be adapted for all junior doctors before engagement to their future jobs and certificate given, therefore many health directorate in Iraq start this training program for three weeks duration and essential ethical and communication issues and clinical training was conducted during the residency period.

Regarding the suggested training program, Yee etal [13] 2006 conducted a study in KualaLumpour, Malaysia to assess the effectivity of medical educational strategies for both graduated and post-graduate students in order to determine the efficiency of the educational level before and after graduation for preparing an advanced training program for future work in the hospital.

They found that students prefer a more skilled practical program than the theoretical one because of the necessity to these skills in their duty life.

Western Australia (WA) [14] metropolitan hospitals provide leading clinical research for teaching the medical graduates across all major branches and these hospitals provide scientific comprehensive relevant medical training through a hospital culture by concentrating on clinical and unit-based teaching programs designed and supervised by each department.

The department of postgraduate medical education in each tertiary hospital supplement an extensive advanced teaching program for graduates to continuously improve their clinical knowledge, skills and communications. The program includes (Grand Rounds, Case study / clinical meeting, Support and monitoring aspect ). Supplemented courses in teaching and learning on the run with updated and immediate life support and lastly medical emergency team training for urgent cases. 
For future suggestions of improving these programs, a study was done by Lynn etal [15] about the preparedness of newly graduated doctors for future practice on four UK setting, England, North Land, Scotland and Wales by taking 185 participants engaged in 101 narrative interviewees (27groups and 84 individuals with 26 junior doctors in their first graduation period to assess the issues about the long term preparedness of newly graduated doctors in terms of stakeholders perceptions about doctors practice and to which extent other various factors play a role in their duty and the possible suggestions for improved their practice ).

They found that 506 junior doctors were prepared well and 683 unprepareds for future work and they explained these results because doctors defect in preparation especially in communication, examination with practical skills while for knowledge aspect they show a good parameter .

On the other hand, the type of teaching method may play a certain specific factor in training and practicing because problem translating knowledge into practice is more beneficial and useful than lecture-based teaching due to engaging them in practicing and managing cases with the relevant discussion in team groups. They suggested that the educators system should try more better efforts to develop an advanced educational supporting program that must be appropriate for specific field practice and certain behavioral skills must be included to increase doctors ability.

Conclusions:

1- The need for advanced updated training program

2- More concentration for both basic and clinical skills for future practicing

3- Training program must b mandatory for newly graduated doctors for about 3-4 months period

Recommendations:

1- Large big study sample on different populations to assess the affectivity of doctors for practicing and managing cases

2- More financial resources to support these programs with the need for Collage assistance

3- Hospital - based training through out the study period is very much effective and give a good results for future preparedness.

\section{References :}

[1] Hays R, Bashford L. Being an external examiner: what you need to know and do. Clinical Teacher $2009 ; 6(3): 160-163$.

[2] Prince KA, Boshuizen HP, Van der PM. Students' opinions about their preparation for clinical practice. Med Educ 2005;39:704-12.

[3] Hausberg MC, Hergert A, Kröger C, Bullinger M, Rose M, Andreas S . Enhancing medical students' communication skills: Development and evaluation of an undergraduate training program. BMC Medical Education , 2012; 12.

[4] De Haes JCJM, Oort FJ, Hulsman RL . Summative assessment of medical students' communication skills and professional attitudes through observation in clinical practice. Medical Teacher, 2005 ; 27: 583-589.

[5] Nicholson, S. "Barriers to Entering Medical Specialties". NBER Working Paper No. 9649. 2003.

[6] Lakhan SE ."Diversification of U.S. Medical Schools via Affirmative Action Implementation". BMC Medical Education.2003. 
[7] West CP, Shanafelt TD, Kolars JC . "Quality of Life, Burnout, Educational Debt, and Medical Knowledge Among Internal Medicine Residents". JAMA: the Journal of the American Medical Association.2011; 306 (9): 952.

[8] Majumder MA. Today's student tomorrow's physician: Emerging challenges for

[9] undergraduate medical education. Bangladesh Med J 2003; 32:84-7.

[10] Al-Gendan YM, Al-Sulaiman AA, Al-Faraidy A. Undergraduate curriculum reform in Saudi medical schools: which direction to go? Saudi Med J 2000; 21:324-6.

[11] Schwarz MR, Wojtczak A. Global minimum essential requirements: a road towards competence-oriented medical education. Medical Teach. 2002; 24:125.

[12] Farhana Ara, Choosing the right course for training program to junior doctors, Medical Educ J 2012; $2:-2-5$.

[13] Syed Hussein The Ministry of Higher Education and Scientific Research and the Ministry of Health of Iraq, in collaboration with the World Health Organization(WHO), workshop to improve the quality and relevance of medical education in Iraq, Amman, 27 February 2012.

[14] Yee HY, Radhakrishnan A, Ponnudurai G.. Improving PBLs in the International Medical University: defining the 'good' PBL facilitate Med Teach. 2006 Sep;28(6):558-60.

[15] International medical graduates in Western Australia, Registration for international medical graduates, Australian Medical J July / 2008; 1:3-6.

[16] Lynn V M, Alison B, Gerard G, Kathrin K , Narcie K. , Camille E R , Karen M,

[17] Charlotte R, New graduate doctors preparedness for practice: a multistakeholder, multicentre narrative study, BMJ open 2018; 8(5):1-5. 